\title{
Campylobacter fetus subsp. fetus bacteremia in a patient with myelodysplastic syndrome: A case report
}

\author{
Hatice Türk Dağı ${ }^{1}$ Ayşe Rüveyda Uğur ${ }^{1}$, Mehmet Dağıı, İnci Tuncer ${ }^{1}$ \\ ${ }^{1}$ Department of Microbiology, Faculty of Medicine, Selçuk University, Konya, Turkey \\ ${ }^{2}$ Department of Hematology, Faculty of Medicine, Selçuk University, Konya, Turkey
}

\begin{abstract}
Campylobacter fetus is an important pathogen of extra intestinal infections in patients with immunodeficiency. A case of Campylobacter fetus subsp. fetus bacteremia in a patient with myelodysplastic syndrome was presented in this study.

A 78-year-old woman with myelodysplastic syndrome was admitted to the emergency due to chest pain and dyspnea. A diagnosis of pneumonia was made, and blood, throat, and urine samples were obtained for microbiological tests. Trimethoprim-sulfamethoxazole and piperacillin-tazobactam were empirically initiated. C. fetus subsp. fetus was isolated from blood cultures and clarithromycin was added. The patient responded an overall 21-day antimicrobial treatment. Because repeated blood cultures were negative, and her general condition improved, upon that she was discharged from the hospital.

In conclusion, the incidence of $C$. fetus infections was low, and case reports are rare in current literature in Turkey. The infections can occur with these bacteria should not be overlooked in the clinical laboratory. J Microbiol Infect Dis 2014; 4(4): $165-167$
\end{abstract}

Key words: Campylobacter fetus subsp. fetus, bacteremia, myelodysplastic syndrome

\section{Miyelodisplastik sendromlu bir hastada Campylobacter fetus subsp. fetus'e bağlı bir bakteriyemi: Olgu sunumu}

\section{ÖZET}

Campylobacter fetus immün yetmezliği olan hastalarda bağırsak dışı enfeksiyonların önemli bir etkenidir. Bu çalışmada miyelodisplastik sendromlu bir hastada C. fetus subsp. fetus'e bağlı bir bakteriyemi olgusu sunuldu.

Miyelodisplastik sendrom tanısı olan 78 yaşında kadın hasta, solunum sıkıntısı ve göğüs ağrısı şikayeti ile acile kabul edildi. Hastaya pnömoni tanısı konuldu ve mikrobiyolojik testler için kan, boğaz ve idrar örnekleri alındı. Ampirik olarak trimetoprim-sulfametaksazol ve piperasilin-tazobaktam başlandı. Kan kültürlerinden C. fetus subsp. fetus izole edildi ve tedaviye klaritromisin eklendi. Hasta toplam 21 gün antibiyotik tedavisi aldı. Genel durumu düzelen hasta tekrarlayan kan kültürlerinde üreme olmaması üzerine taburcu edildi.

Türkiye'de mevcut literatürde $C$. fetus enfeksiyonlarının insidansı düşüktür ve olgu raporları nadirdir. Bu bakteri ile oluşabilecek enfeksiyonlar klinik laboratuvarlarda göz ardı edilmemelidir.

Anahtar kelimeler: Campylobacter fetus subsp. fetus, bakteriyemi, miyelodisplastik sendrom

\section{INTRODUCTION}

The Campylobacter genus is a Gram-negative, curved microorganism including 143 species within the NCBI Taxonomy. ${ }^{1}$ Campylobacter is a significant pathogen of intestinal infections in human being. This microorganism sporadically causes bacteremia or extra intestinal infections. Although intestinal infections are usually caused by Campylobacter jejuni, Campylobacter fetus is the important causative microorganism of extra intestinal infections. ${ }^{2-4}$ C. fetus subsp. fetus causes infertility and miscarriage in sheep, goats, and bovine. Additionally it is an opportunistic pathogen in humans, mostly immunocompromised and elderly patients. At first the bacterium causes gastroenteritis, and then dissemi-

Correspondence: Hatice Türk Dağı, Department of Microbiology, Faculty of Medicine, Selçuk University, Konya, Turkey Email: haticeturkdagi@yahoo.com 
nates throughout the blood and causes meningitis and other systemic infections via bacteremia. ${ }^{2}$

We report a case of $C$. fetus subsp. fetus bacteremia in a patient with myelodysplastic syndrome.

\section{CASE PRESENTATION}

A 78-year-old female patient with myelodysplastic syndrome was admitted to the emergency room due to chest pain intensifying with inspiration and difficulty in breathing. Physical examination was unremarkable except for diminished breath sounds and bilateral crackles over the lower lung fields by auscultation. Vital signs revealed a blood pressure of $110 / 70 \mathrm{mmHg}$, an apical heart rate of $78 /$ minute, a respiratory rate of $16 /$ minute, and a body temperature of $38.6{ }^{\circ} \mathrm{C}$. Her leukocyte count was 30.7 K/uL ( $94 \%$ polymorphonuclear cells), erythrocytes $1.68 \times 10^{6} \mathrm{~K} / \mathrm{uL}$, hemoglobin concentration $5.14 \mathrm{~g} / \mathrm{dL}$ and platelet count $708 \mathrm{~K} / \mathrm{uL}$. Her C-reactive protein level was $379 \mathrm{mg} / \mathrm{L}$, procalcitonin $8.5 \mathrm{ng} / \mathrm{mL}$. Chest $x$-ray revealed bilateral patchy infiltrates intensifying at the right lower lobe segment. $\mathrm{O}_{2}$ saturation was $90 \%$.

After a diagnosis of pneumonia had been made, blood, throat, and urine samples were obtained for microbiological tests. Sputum specimen could not be obtained. Then trimethoprim-sulfamethoxazole $(800 / 160 \mathrm{mg})$ t.i.d, po) and piperacillin-tazobactam $(4.5 \mathrm{~g})$ t.i.d, i.v) treatments were promptly initiated as empirical therapy. Four units of packed red cells were transfused. Recombinant erythropoietin was administered for treatment of MDS. Cytotoxic chemotherapy was not administered to the patient.

The patient recovered clinically, and her respiratory findings improved but she still had fever. While urine culture and throat swab yielded no pathogen, blood cultures obtained on admission were positive for spiral-shaped gram-negative bacilli with a typical view of Campylobacter species. Upon receiving culture results of growth of $C$. fetus subsp. fetus in two consecutive blood samples, clarithromycin (500 mg, b.i.d, p.o.) was added on the $8^{\text {th }}$ day of the present regimen. She denied any recent gastrointestinal disturbances like diarrhea but described an abdominal pain before her admission. The patient had a history of contact with bovine and sheep products. Her stool culture didn't yield growth of $C$. fetus. The patient responded the overall 21-day antimicrobial treatment and her fever, the C-reactive protein and procalcitonin levels declined day by day. Repeated blood cultures were negative. Her general condition improved and upon that she was discharged from the hospital.

\section{BACTERIOLOGICAL METHODS}

Blood samples were inoculated in aerobic blood culture vials (aerobic bacteriological media: BD BACTEC $^{\text {TM }}$ Plus Aerobic/F Medium (Becton-Dickinson Diagnostic Systems, USA). The vials were monitored by the BACTEC ${ }^{\mathrm{TM}} 9120$ fully automated blood culture instrument (Becton-Dickinson Diagnostic Systems, USA). The vials with a positive signal were stained with Gram stain and aliquots of $0.1 \mathrm{~mL}$ were subcultured on Columbia agar with $5 \%$ sheep blood, eosin methylene blue (EMB) agar and Campylosel agar (bioMérieux Clinical Diagnostics/ France). EMB and Columbia agar with 5\% sheep blood were incubated aerobically, and Campylosel agar was micro-aerobically incubated $\left(5 \% \mathrm{O}_{2}, 10 \%\right.$ $\mathrm{CO}_{2}$ and $85 \% \mathrm{~N}_{2}$ ) at $35^{\circ} \mathrm{C}$. After 48 hours incubation, growth of tiny and sprawling gray colonies was seen. Spiral-shaped and thin Gram-negative bacilli were showed on Gram stain.

The identification of bacteria were performed by traditional methods (catalase, oxidase and motility tests; positive) VITEK® MS, an automatic microorganism identification system that uses mass spectrometry technology (Matrix-assisted laser desorption ionization time of flight, MALDI-TOF) (bioMérieux Clinical Diagnostics, France). The antibiotic susceptibility tests were performed by E-test method (PDM Epsilometer; AB Biodisc, Sweden) on Mueller-Hinton agar with $5 \%$ sheep blood. The minimum inhibitory concentrations (MICs) of the isolate were $0.38 \mu \mathrm{g} / \mathrm{mL}$ for ampicillin; $0.25 \mu \mathrm{g} / \mathrm{mL}$ for tetracycline; $0.75 \mu \mathrm{g} / \mathrm{mL}$ for erythromycin and gentamicin; $0.2 \mu \mathrm{g} / \mathrm{mL}$ for ciprofloxacin; $256 \mu \mathrm{g} / \mathrm{mL}$ for piperacillin-tazobactam; $0.015 \mu \mathrm{g} / \mathrm{mL}$ for imipenem, and $24 \mu \mathrm{g} / \mathrm{mL}$ for ceftazidime. MICs were interpreted according to the breakpoints published by the Clinical Laboratory Standards Institute. ${ }^{5}$

\section{DISCUSSION}

Campylobacter is a significant pathogen of a wide range of diseases in humans. Most common cause of intestinal infections is $C$. jejuni. Extra intestinal infections such as endocarditis, meningitis, osteomyelitis and septic arthritis are rare and caused mostly by other species. ${ }^{3}$

Campylobacter sp. colonizes various hosts from farm animals to humans with different degrees of virulence. Among them, C. fetus strains are sep- 
arated into two subspecies, C. fetus subsp. venerealis and C. fetus subsp. fetus. ${ }^{6}$ C. fetus subsp. venerealis causes venereal diseases in cattle and is rarely associated with human infection. On the other hand, C. fetus subsp. fetus infects bovine, sheep, goats, and humans. The microorganism may be delivered by an injury or mostly consumption of contaminated food or water. ${ }^{7}$

C. fetus is primarily related with bacteremia because of its tropism for vascular bed, seeding preexisting lesions. ${ }^{8}$ Bacteremia caused by $C$. fetus is a severe infection frequently accompanied by recurrences and complications in spite of administration of proper antibacterial therapy without any delay. ${ }^{6}$ In immunocompromised patients, lung abscess, prosthetic hip joint infection, septic arthritis, vertebral osteomyelitis, spontaneous bacterial peritonitis, and cholecystitis are among the diverse complications of $C$. fetus bacteraemia. ${ }^{7,9-12}$

C. fetus bacteremia has also been rarely reported in immunocompetent patients. Human immunodeficiency virus infection, primary immunodeficiencies, liver cirrhosis, alcoholism, senility, pregnancy, diabetes mellitus, haematological and solid organ malignancies or transplantation, systemic lupus erythematosus, and splenectomy are significant predisposing factors for $C$. fetus infections. ${ }^{4,13}$

Our research has found a single case in Turkey. In this case, a 92- year-old male patient with secondary chronic renal failure due to pyelonephritis developed bacteremia possibly after a gastrointestinal infection caused by $C$. fetus subsp. fetus was reported. ${ }^{14}$

In our patient, myelodysplasia could have been contributing factor to the bacteremia. In our case, because any respiratory specimen could not be obtained, and stool culture didn't yield growth of $C$. fetus, the source of primary infection side could not be identified. Because the patient's respiratory distress responded to piperacillin-tazobactam therapy and $C$. fetus is resistant to piperacillin-tazobactam, it was not likely that the pneumonia resulted from C. fetus bacteremia. However, C. fetus bacteremia developed possibly after a gastrointestinal infection without diarrhea, because she described an abdominal pain before her admission. Unlike $C$. jejuni, C. fetus rarely causes diarrhea, but it is known to cause isolated bacteremia. ${ }^{15}$

A limitation of our study is the absence of the molecular analysis in the bacteriological identification. Correct identification needs molecular analysis, but we could not use molecular methods for a single case because of the high cost. Biochemical identification and MALDI-TOF is used to identify $C$. fetus. ${ }^{15}$

In conclusion, despite C. fetus infections are low, and case reports are rare in current literature, the actual incidence of Campylobacter infections has not been known due to its rare occasion and the specific growth conditions. For this reason, the possibility that infections can occur with these bacteria should not be overlooked in the clinical laboratory.

\section{REFERENCES}

1. https://www.ncbi.nlm.nih.gov/Taxonomy/Browser/wwwtax. cgi?id=194. The last accessed date: 21.03.2014

2. Moolhuijzen PM, Lew Tabor AE, Wlodek BM, et al. Genomic analysis of Campylobacter fetus subspecies: identification of candidate virulence determinants and diagnostic assay targets. BMC Microbiology 2009; 9:86

3. Fernández Cruz A, Muñoz P, Mohedano R, et al. Campylobacter bacteremia: clinical characteristics, incidence, and outcome over 23 years. Medicine 2010; 89:319-330.

4. Zonios DI, Panayiotakopoulos GD, Kabletsas EO, et al. Campylobacter fetus bacteremia in a healthy individual: clinical and therapeutical implications. J Infect 2005; 51:329-332.

5. Clinical and Laboratory Standards Institute. Methods for Antimicrobial Dilution and Disk Susceptibility Testing of Infrequently Isolated or Fastidious Bacteria; Proposed Guideline. CLSI document M45-P. CLSI, Wayne, Pennsylvania, USA, 2005.

6. Ali A, Soares SC, Santos AR, et al. Campylobacter fetus subspecies: Comparative genomics and prediction of potential virulence targets. Gene 2012; 508:145-156.

7. Targan SR, Chow AW, Guze LB. Campylobacter fetus associated with pulmonary abscess and empyema. Chest 1977 71:105-108.

8. Martínez Balzano C, Kohlitz PJ, Chaudhary P, Hegazy H. Campylobacter fetus bacteremia in a young healthy adult transmitted by khat chewing. J Infect 2013; 66:184-186.

9. Yao JD, Ng HM, Campbell I. Prosthetic hip joint infection due to Campylobacter fetus. J Clin Microbiol 1993; 31:3323-3324.

10. Yamashita K, Aoki Y, Hiroshima K. Pyogenic vertebral osteomyelitis caused by Campylobacter fetus subspecies fetus. A case report. Spine 1999; 24:582-584.

11. Barrio J, Castiella A, Gil I, et al. Spontaneous bacterial peritonitis by Campylobacter fetus in Budd-Chiari syndrome without liver cirrhosis. Liver1999; 19:69-70.

12. Takatsu M, Ichiyama S, Nada T, et al. Campylobacter fetus subsp. fetus cholecystitis in a patient with advanced hepatocellular carcinoma. Scand J Infect Dis 1997; 29:197-198.

13. Ledina D, Ivić I, Karanović J, et al. Campylobacter fetus infection presenting with bacteremia and cellulitis in a 72-yearold man with an implanted pacemaker: a case report. J Med Case Rep 2012; 6:414.

14. Tatman Otkun M, Aydın Tutak G, Gülsen E, Ozgen Z. A Case of Bacteremia Due to Campylobacter fetus subsp. fetus and Importance of Gram Stain at Laboratory Diagnosis. Turk Hij Den Biyol Derg 2009;66:21-24.

15. Cypierre A, Denes E, Barraud O, et al. Campylobacter fetus infections. Med Mal Infect 2014; S0399-077X(14)00029-8. doi: 10.1016/j.medmal.2014.02.001. 